I bless God for my first book, and for a pious mother and father to hear me and teach me in it. It was better to me than all the other books of my childhood. I have even forgotten the names of some others, but this little child's book is fresh in my memory. There was the picture of Zacheus "climbing a tree, his Lord to see;" of John Rogers burned at the stake, for believing in Jesus Christ, and above all the cross representing where

\title{
Christ crucified
}

For sinners died.

The truth to be drawn from this story of my first book is this: First feelings and thoughts, first lessons and objects in life are never forgotten. Fill the mind with good thoughts and feelings in childhood, and in youth, and mature years, and old age, the lines of the first book will be written on the memory for all this life and the life to come.

God blesses early impressions. He loves the little child so easily turned to think of Jesus. And, if the little one dies in childhood, it has begun thus to learn of heaven, where by the spirit of God it may be prepared to enter.

\section{MY SCHOOLS AND MY SCHOLARS.}

Among other schools, I taught in Canandaigua Academy in 1831, and again in 1836-38, and also in 1849-nearly three years in all. And I purpose to publish some crumbs of correspondence of pupils and parents, illustrating early life. In general, names are represented only by initials.

We preface the article on Schools and Scholars with a Latin poem, translated by Mr. Stevenson, an early principal of Canandaigua Academy; he was a jolly old man when he gave the translation to the editor, then a classical teacher in the Academy. Also, a sketch of Ezekiel Cheever, the first teacher of note in New England.

Would all parents be as faithful as N. W. H. to his son P. for truancy, teachers would fare better.

The letters of Mrs. Spencer reminds me of her poor son Philip, who was hung at the yard-arm at sea, by order of 
Captain McKensie, in a cowardly manner. But $I$ have not time to write the history of Philip S. McKensie was never after entrusted with a war vessel. - [EDIToR, S. S. H.]

\section{DULCE DOMUM.}

Concinamus, O! sodales, Eja! quid silemus?

Nobile canticum,

Dulce melos domum

Dulce domum resonemus.

Domum, domum, dulce domum, Domum, domum, dulce domum, Dulce, dulce, dulce domum

Dulce domum resonemus.

Appropinquat, ecce! felix

Hora gaudiosum;

Post grave tedium

Advenit omnium,

Meta petita laborum.

Domum, ete.

Musa, libros mitte, fessa Mitte pensa dura,

Mitte negotium,

Jam datur otium, Me mea mittito cura.

Domum, etc.

Heus, Rogere, fer caballos,

Eja! nunc eamus,

Domum amabile;

Matris et oscula,

Suaviter ut repetamus.

Domum, etc.

(Translated by Mr. Stevenson, aged 75 years, 1837.)

HOME, SWEET HOME.

Tune your voices, O! my classmates,

Why this gloomy silence?

Join in a noble song,

Thrice happy, happy home!

And home, sweet home, the chorus. 
Home, home, sweet home!

Home, home, sweet home!

Sweet, sweet, sweet home!

0 ! sing sweet home in chorus.

See! Approach, the gladsome season,

Free from all vexation;

After a time of toil,

Who can without a smile

Hail the sweet joys of vacation?

Home, etc.

Tired out muse, dismiss your classic,

Books and tasks laborious;

Drive wrinkled care away,

Give us mirth, sport, and play.

Now, let these be victorious.

Home, etc.

Coachman, coachman, bring the horses,

Quick; let us be flying;

Soon the dear lovely home,

Soon mamma's kisses warm,

We shall be sweetly enjoying.

Home, etc.

\section{MEMOIRS OF EZEKIEL CHEEVER.}

Cheever, Ezekiel, an eminent instructor, born in London, January 25th, 1615, came to this country in June, 1637, for the sake of the peaceable enjoyment of Christian worship in its purity. He was first employed as a schoolmaster at New Haven, for twelve years; then at Ipswich, Massachusetts, eleven years; and afterwards at Charlestown, nine years.

He removed to Boston, January 6 th, 1671, where he continued his labors during the remainder of his life. He died, August 21st, 1708, in the ninety-fourth year of his age.

Most of the principal gentlemen in Boston, at that time, had been his pupils, and took pleasure in acknowledging their obligations, and honoring their old master. $\mathrm{He}$ was not only an excellent teacher but a pious Christian. He consequently prayed with his pupils every day, and catechized them every week. He also took frequent occasions to address 
them on religious subjects. Being well acquainted with divinity, he was an able defender of the faith and order of the gospel.

In his old age his intellectual powers were very little impaired. He published an essay on the millennium, and a Latin Accidence, which has passed through twenty editions, and has not lost its reputation to the present day.-From Allen's Biographical Dictionary, published 1809.

\section{EPITAPHIUM.}

EZEKIEL OHREVERUS.

Ludimagister;

Primo Neoportensis;

Deinde, Ipsuicensis;

Postea, Carolotenensis;

Postremo, Bostonensis;

cujus

Doctrinam ac Virtutem

Nosti, si sis Nov-Anglus,

Colis, si non Barbarus;

Grammaticus,

a Quo non pure tantum, sed et pie,

Loqui;

Rhetoricus,

a Quo non tantum ornate dicere

coram Hominibus,

sed et Orationes coram Deo fundere

Efficacissimas;

Poeta,

a Quo non tantum Carmina pangere,

sed et

Colestes Hymnos Odasque Angelicas, canere

Didicerunt,

Qui discere voluerunt;

LUCERNA,

ad Quam accensa sunt,

Quis queat numerare,

Quot Ecclesiarum Lumina?

Er

Qui secum Theologiæ abstulit,

Peritissimus Theologus,

Corpus hic suum sibi minus charum, deposuit. 


\author{
Vixit Annos XCIV. \\ Docuit, Annos LXX. \\ Obiit, A. D. M.DCC.VIII. \\ Et quod mori potuit, \\ HeIc \\ Expectat Exoptatque \\ Primam Sanctorum Resurrectionem \\ ad \\ Immortalitaiem.
}

CRUMBS OF BOYS' CORRESPONDENCE.

$M r$. S. S. Howe:-Will you please to examine James' composition again? I know he wrote it and made an extra exertion to give satisfaction to his teachers. M. W. S.

Mr. Howe:-Walter was detained by me this morning.

E. M. $\mathbf{H}$.

Mr. Howe:-Please excuse Master Philip at four o'clock. We wish to send him down street.

E. S. S.

It will give me pleasure, Mr. Howe, to have you call over to-morrow, or any time that you have leisure. I want to talk over that "Tittle matter" about Philip. As he is so very sensitive on the subject, I told him I would see you myself before he went to school again. He had a severe attack the night before, so that we sent for the doctor, and he is hardly well enough to be out to-day. With respect,

E. S. S.

Mr. Howe:-I detained P. yesterday. This forenoon he was absent from school without leave. I have inflicted upon him adequate corporal punishment, and my object in writing this note is to request you to give him a severe admonition in the hearing of the school. You may perhaps be able, under God, to touch his heart, and do him everlasting good.

I am very truly, your friend, N. W. H.

Dear Sir:-I shall be glad that John study anything you approve of. All I meant by saying to him that I saw no occasion for his accounting from Wilson's arithmetic, was that I considered he might learn as well from the book he already 
had; but if it suits you better that he should work from the other, he can procure it. Yours very truly, W. W. R.

$\$ 0.10$.

Canandaigua, July 31st, 1838.

Due the missionary fund, ten cents, for value received.

C. K.

Mr. Howe:-I will tell you some things I have done this term. Your brother reproved me once for bad conduct, but I do not remember what it was. And you did the same this morning for looking off of my book. Also last Sunday for spitting on the floor twice. And at the dinner table you repreved me for speaking to you very improperly. I suppose you took it as an insult, but I did not intend it should be. I hope I shall let all my tricks alone and let them go away from me.

A. P. C.

Mr. H. Howe:-I take this opportunity of asking you if you will not excuse me from writing a composition for examination. My reasons are these: I have never written one for examination, inability at this time to write, and want of time. These are my excuses; if they seem enough to excuse, please excuse me; if not, I must yield to the powers that be. Humble yourself so low as to answer this, and believe me your obedient scholar,

J. S. S.

A fine scholar; died young at Auburn, N. Y.

Mrs. Howe:-Hearing that you was very much displeased with me and demanded an apology, I take this early opportunity to inform you of the circumstances. A. H. Dey was to sleep with me. I asked him the night before. In Joseph Sherwood's room I said my bed would hold three. The boys all (with three exceptions) make it a practice to travel about to each other's rooms. This practice I am not disposed to favor. We were not aware that we made so much noise. We must confess it was very improper and ungentlemanly. But we still hope by confession of guilt, we may be able to insure future respect and regard, and a forgiveness of the past offence or offences.

Believe me your obedient boarder, F. B. 
Mr. Howe:-I wish to inquire whether you would like to hear me speak a piece this evening (as I have not spoken this term) to see if I can so speak as to answer for the exhibition.

G. J. H.

Mr. S. S. Howe:-It was me that threw the paper wad this morning and hit A. P. C. Please excuse me for this time only.

R. A.

Dear Sir:-I am sorry to find that latterly you have not treated me as the rest of the boys, and therefore $I$ infer that there is something in my conduct that displeases you. If so, I should like very much to find out what it is, and I will endeavor to correct my conduct so as to please you in all things and to act as becomes one of my station. You might have thought that my sickness this afternoon was more affected than real, but it was not. Some time since I was subject to dizziness in my head occasioned by a fall, but have not had it much lately. Therefore I deem it my duty to write you this apology, if it will be accepted by you, and sincerely hope you will overlook it this time.

Your (hereafter) faithful pupil, R. K.

$M r$. Howe:-I wrongfully wrote on the house in question and have fastened myself in there in order to escape the boys. I saw on the day the men were repairing it, H. N. take an augur and bore holes in it. He also took a chisel and $I$ believe cut the house; this was when the men were at dinner. This is all that took place last term. Day before yesterday I. S. took refuge in one, and I threw a snowball in at him. I have at no time used a knife upon the building, nor thrown clubs or stones into the trough. I have heard to-day that the door was torn down by C. R. or S. L. This, Mr. Howe, is the true history of my faults.

From your affectionate pupil, J. R. L.

Mr. Howe:-All that I know about this affair is, I wrote a riddle on the outside of one of the doors last winter. I do not know of anybody doing anything at all. I have told the truth and nothing but the truth.

S. W. W. 
Mr. Howe:-I think whispering is a very bad practice, and I will try to offend no more.

E. G. D.

A very good scholar, and died young at Detroit.

Mr. Howe:-I whispered twice-once I asked T. F. Rochester how to spell a word. The other time S. W. Whitney and H. B. Livingston were talking about what animals there were in a show. H. B. L. asked S. W. W. what animals there were, and I said llama. I acknowledge that I did wrong, and promise not to do so any more; at least I will try.

T. D. P.

Mr. Howe:-Whispering is a very bad practice. This morning I was told to stop whispering. I asked the boy to put my name in his composition. I don't mean to follow the practice.

S. B.

\section{PLEDGE.}

We, the subscribers, do hereby agree not to whisper without permission:
D. H. Fitzhugh,
Augustus Wilson,
W. H. Adams,
G. B. Hubbell,

\section{A. P. Howell.}

\section{MY FATHER'S CANE.}

\section{WHAT A LITTLE VINE DID TO A BIG STICK.}

The Rev. Samuel Storrs Howe, of Iowa City, Iowa, has just called at the Mission House, and as he is something of a veteran he brought with him a curious walking stick. He said that he inherited it from his father, who cut it with his own hands many years ago. From end to end it shows a spiral groove, evidently produced by some little vine, which wound itself around it as it grew, and partially embedded itself in the trunk which it had chosen for its support. It struck me as a beautiful illustration of the fact that there is scarcely any person or thing in the world that does not exert some influence. I was reminded of one little child and another of my acquaintance who had clung with twining 
Copyright of Annals of Iowa is the property of State of Iowa, by \& through the State Historical Society of Iowa and its content may not be copied or emailed to multiple sites or posted to a listserv without the copyright holder's express written permission. However, users may print, download, or email articles for individual use. 